\title{
Leadership and Economic Development of Ghana
}

\author{
David Kwasi Mensah \\ Walden University, USA \\ E-mail:kddmensah@gmail.com
}

Received: April 2, $2021 \quad$ Accepted: May 1, $2021 \quad$ Published: May 2, 2021

doi: 10.5296/jsss.v8i1.18590 URL: https://doi.org/10.5296/jsss.v8i1.18590

\begin{abstract}
The relationship on leadership quality and its impact on skewed economic development in Ghana have been investigated. This investigation has been carried out in Ghana and its neighbouring countries that attained independence around the same time, under similar pattern of political governance. A comparative analysis is used to differentiate between these countries economic policies and their leadership styles used. It reveals that Ghana remains static and underdeveloped for many years despite changes in leadership and political governance. Evidently, while at the time of their independence, Ghana's per capital income in 1960 was higher than Nigeria, India and Egypt. Ghana's development has been sluggish whilst the rest of the countries have accelerated at a faster rate with fantastic economic policies combined with good leadership skills.
\end{abstract}

The way forward towards establishing a sustainable economic development in Ghana includes vision, goals and value of the nation, a strategy for achieving, managing change and national transition.

Keywords: Leadership, Governance Economic development, Political governance Savings Education

\section{Introduction}

\subsection{Leadership}

Leadership as a process where a person influences a team to achieve a goal. It includes attention to common goals, and increases the possibility that both leaders and followers work closely together for a common goal (Rost, 1991). Burns (1978) defined a transformational leader as 'one who raises the followers' level of consciousness about the importance and value of desired outcomes and methods of reaching those outcomes' (p. 141). Strategic leaders have been able to transformed their countries' economies from zero to advance stage. On the other hand, ordinary leaders with poor leadership and structural constraints have disappointed their countries woefully. Leadership design good policies to push forward 
economic management which in turn transformed and achieved social economic development of a country. Such leaders usually have long term vision to pursuit human, natural resources and socio economic infrastructure.

Political leadership comprises the government and its appointed cabinet ministers. They are selected by citizens of a country through the ballot box, coup d'etat or by appointed head of state or president. Political leadership is connected with good economic policies, strong human capital index and good execution of economic development plans. Good development brings joy to the citizens of a country through providing drinking water, raising the standard of education, better job opportunities and sophisticated health care services. Economic development is the transformation of existing economy left behind by the colonial masters, by improving the human capital, infrastructure, education and health care, to mention few. It involves improving the standard of living of the citizen of a nation, good self-esteem of the citizens combined with freedom and justice in the society (Todaro, 2016).

\subsection{Governance}

Governance in general is the term for the way of group of people such as a country does things. Many groups create a government to decide how things are to be done. Governance is also how a government decision affects the people in the nation in terms of social economic development both at macro and micro level. It is therefore claimed that sustained economic development of any nation largely hinges on the effectiveness and efficiency of the governance of the nation concerned. Again such a robust outcome, emerging out of governance depends on the forms of political governance and their respective leadership. Historically, prevailing forms of government include monarchy, aristocracy, oligarchy, democracy, theocracy and tyranny. The main aspect of any philosophy of government is how political power is obtained with the two main processes being electoral context and hereditary succession. These political processes facilitate the emergence of leadership for the respective political group. An overview of prevailing forms of political governance reveals that there are three types of political governance, regardless of the philosophy, the leadership matters from the citizens welfare perspectives of the nation concerned since good leadership is proportionately correlated with good governance resulting a robust economic growth and social welfare development to the people being governed by it.

In the case of Ghana, the nation has produced two forms of leadership that has governed the country (civilian and military) after independence 1957. The circumstance of which Ghana has engulfed itself was determined by the quality and vision of its leaders. Since independence, Ghana has not been lucky to have gotten competent, effective and purpose-driven leaders capable of transforming its great natural potentials into real giant economic gains. The kind of leadership that has govern the nation has led to economic crisis and the country has clogged and probably still clogging on it kneel economic transformation and development. Poor leadership had triggered mismanagement and continuous corruption has impacted the system retarding the smooth economic growth process with equity and inclusiveness in Ghana. Consequent to the above political scenario, Ghana's economy has failed to be recognized as one of the developed country especially in the sub-Sahara Africa due to leadership failure. It is unfortunate that the country has not experienced much transformation after independence despite having unearth natural resources, favourable 
opportunities and climatic conditions as compared to other countries that have miraculously outperformed the country in many sectors of the economy. Ghana's leadership lagged far behind other countries like Singapore and Mauritius in terms of how leadership has influenced positively economic development since independence to date. Ghana was the icon of Africa after attaining independence with high expectation to move the economy to a greater height as to that of Europeans and Asian countries. However, Ghana has failed to produce quality political leadership and this has kept the country in dark undeveloped till date compared to its peers since independence days.

Leadership is the process of influencing the activities of an organizational group in the task of goal setting and goal achievement (Stogdill, 2003). Mac Ogonor and Steve (2000) sees it as process of motivating, mobilizing resources and directing people to passionately, diligently and strategically accept a vision that the people of a state or nation jointly embrace by performing tasks. From the above observation, it is ascertained that a capable leader must possess some positive characteristics, sound knowledge, moral discipline, inspiring charisma, clearer understanding of contextual reality and vision, and as a capable team player.

Analyzing leadership style in Ghana will bring out which leadership style did not favour in governing the citizens so that a change could be done. Whether one is introvert, extrovert, disciplined or action-oriented will perform in one best way for excellent results, the amount of efforts one put differentiate the results. The consistent level of poverty (give data on poverty level in Ghana) in the country predicts that poverty is the effect in which both the society and resources are distributed. The eradication of poverty in Ghana to the minimum level is political and leadership choice about the kind of society we want to live in. During the austerity period, political choices made depended on poverty and inequalities. Having a precarious job limit, access to decent pay and disintegrate people from social network.

The size and the type of family pose a higher risk of poverty because they generate greater cost, low paid income and most difficult in getting a good paid employment. Gender-female pose a target to poverty than their counterpart (men) and are less paid, have low pension and unpaid caring responsibilities for the same job. Ill health or disability limits access to employment which adds day to day cost. Moreover, being born to minority ethnic group and live in the remote or disadvantage community find access to service worse.

All these aforesaid issues pertaining to demography of Ghana continuously are leading to distorted economic development irrespective of changes in the political leadership since independence. As against the premise the paper focuses the efficacy of the political leadership in the given economic status of Ghana and the way forward for bringing Ghana as a developed nation in the world. Following are the specific objectives of the paper.

\subsection{Objectives of the Paper}

a. To discuss the nature of leadership in different political governance in the world and their impact on economic development in the respective countries

b. To critically, analyze the type of leadership prevailed in the political governance of Ghana and its outcome reflected in Ghanaian economy and

c. To suggest a kind of robust leadership that works towards bringing a sustained economic growth and development with poverty alleviation in Ghana. 


\subsection{Literature Review}

The literature review has been attempted to understand the type of leadership and its influence on the respective governance in different countries and followed by Ghana in particular.

\subsubsection{Leadership Political Governance and Economic Development}

After gaining independence from the British in 1957, both Ghana and other sister countries (Malaysia, India, Singapore, Nigeria, and Egypt) were similarly at the same par of economic development. In reality, Ghana's per capital income slightly overshadow these nations and better infrastructure as similar of today. All these countries benefited the same colonial structures from their master (British), in addition to the market economic structure. Ironically, Ghana's chances of success after independence was higher than those countries mentioned. Since then, Ghanaian economy has been inert whereas other nations economy accelerated at a faster rate and in a sustained growth rate. As at today, the real per capital income of these countries are five (5) times heavier than Ghana. Sixty (60) years later, these countries are in upper-middle income country and Ghana regarded as a lower middle income country. During the colonial time, all these countries were primary commodity producers. For example, Malaysia planted rubber and later oil palm trees, as well as harvesting timber and mining tin. On the other hand, Ghana, grows cocoa, mining gold, diamond, bauxite and manganese. The period after independence pinpointed these countries making extra effort to restructure the economies to assist the native population. Ghana sent good bye to the British whereas Malaysia encouraged the British to help transform their economy.

All these nations adopted the development plans, but in different directions in the 1960s. These countries plans were more indicative, through which the private sectors pursued their business activities. The literature indicated that Ghana planned to follow industrialization quickly after independence through establishment of state enterprises. There was the failure to bite low productivity in the agriculture sector and depending on one major export crop, cocoa, made it too difficult to pursue industrialization. Instability created by rapid coup d'etat in the 1960s through the 1980s created environmental that scared foreign direct investment and strong private initiative.

The growth strategies used by these nations were due to good economic policies, good omen and pragmatism. These countries enjoyed stable governance through coalition of inclusive governance. As a result, there was no gap in development planning. They also planted good institutions and adoption of new technology. This led to the rapid growth of these countries through the process of economic development.

The current politics of South Africa shows that fear is crippling South Africans due to the fact that it may be another failed state. This is due to the abuse of power, lack of accountability, corruption by the executives of the South Africa government, lack of management, governance and trustworthiness. Servant leadership is urgently needed for the current state of political leadership in South Africa. The aspect of the current political leadership. Abused of power was a great concerned. After the interim constitution was incorporated in 1994, it reversed years of colonial and apartheid policies of racial fragmentation and marked a new beginning of South Africa. The courts were the ultimate guardian of the constitution and were 
duty bound to protect it when attempted to violate it (Mojopelo, 2013). Surprisingly, the political leadership under president Jacob Zuma ignored the separation of powers and did not act within their boundaries but overlapped into other institutions.

Corruption was the second aspect of political leadership and ignorance to combat it. Government failure to fight corruption was a symptom of weak management and operation system which created space of corruption to thrive. Habternichael (2009) stated new form of mechanisms needed to emerge in anti-corruption programmes. Corruption which was like a virus spread through the new government. It acted as a dynamic and complex social phenomenon. There were also lacks of public accountability. Public accountability allowed the entrusted persons with public resources to be answerable for the fiscal, managerial and programmes responsibilities that have been put into their care and report to those that have conferred those responsibilities. Public entities which capitalized on public resources had an obligation to account for the way these resources were allocated, the outcomes of these spending had progress. Too much power had been breed by contempt for public impunity and lack of accountability.

Keof principles of servant leadership meant service. A servant leader makes followers independent, capable and desirous to serve other persons. They admire the spirit of servant leadership, spirit of normal moral authority (Covery 2002). Servant leadership is an integral part of serving, all people involved within the organization (Relschman, 2002). The four role of servant leadership are that the leader must be first a model of credibility, diligence and spirit of servant leadership. The second role is path finding, where a vision is discerned. The third role is alignment, which allows one to institutionalize value and the fourth is to empower persons, the fruit of the first three roles (Walls, 2004).

Servant leadership has the potential for maximizing empowerment participation because it values the importance of each individual. It is humility. This is a great challenge which leads to true discipleship that leads to servility. Humility is looking at the outward action of the persons other than the heart. Normally, persons will perceive meek persons as humble. In Africa culture, a person cannot claim to be humble until there is an act of humility. When people observed those rules and regulations, they are classified as humble.

\subsubsection{Governance and Leadership in Different Countries}

Governance and leadership has been expressed in several ways among different countries. According to Lewis Galaniiere, United States of America (USA) starts to assemble and exploit wealth and power, secrete dynamic cultural pushes within itself. A nation with such a small beginning attained to world leadership maintain the rank only so long as its culture, achievements in humanities command respect and degree of emulation. It is believed that leadership is taken over by power, it maintained through a span of time, with free asset of the led, which gives free only and not material authority. Britain transformed itself into world leadership in the $19^{\text {th }}$ century and continues to maintain it due to her reputation, fair play, honest accounts, incorruptible law courts and political system which were acceptable by the world. The richest and populous nations were reigned by brilliant generals and cabinet secretaries. Men of affairs in politics in the states, and in business had exercised their function in relative tranquility, and their intelligentsia, free of obfuscations of the mind and torments of spirit engendered by ideological passions, have created works of imagination out 
of hearing of the hurly-burly of everyday world. America has problems but it stands before them in full view, which can be solved by reason, negotiation, compromise and administrative measures. The Russians called us 'economic imperialists' thus trying to pour our surplus goods into their markets, we might have great unemployment. The American economic system is one of the alternate bust and boom which guarantee no scarcity to any nation nor rich enough in resources to accept the risk involved in a crazy system. It has made the American people to succeed very well in any history. In a world of political power of centralization, it has been able to preserved self-reliance and autonomy of local community. Also in a world where economic concentration is inescapable, there is accomplishing the separation of economic power and political power. Economic leaders have had respect through public opinion which has been characterized by political leaders. America has a horizontal society in which every person feels connected with each neighbor and join in groups in a sense of collective responsibility. Not all Americans are self-reliant with a sense of responsibility for their communities nor every American community is without a faction healthy bred of indispensable political rivalry. Americans believed that they prefer to support government than government supporting them.

Constantin et al. observed that the Eastern European States have been the boiling point between Russia leadership and the European Union leadership since 1990. USSR folding up and the new reemergence of Eastern Europe in modern European politics have created a lot of opportunities for each colonial blocks to reinforces and manage their leadership styles. Dynamics of European politics have changed so also is the new Russian politics in the century. Vladimir Putin and his influence of politicians have pushed forward strong leadership style and reinforced it in part, of the international politics. Eastern European states have been a puppet to USSR and joined a strong linked with Russia till today.

EU-Ukraine -Russia relation at the start of the new millennium.

The dynamics of outside Russia borders have been one of the interesting aspect of international politics today. The effect of Europeanization process and its limitations is based on ideas of misfit between ideas, values and institutional processes of targeted country and the EU, a scenario that helps to foster change (Borzel, Risse, 2000, p. 2). The relationship between EU and Ukraine has made a strong impact in symmetrical, at top-down logic (Franke, Gawrich, Melnykovaska, Schwelckert, 2010, p. 150).

Pressure from EU on Ukraine has blotted over the years with a strong impact as it stands today. European Union target on Ukraine was to democratized the system as a result of the 2004' orange revolution' which demanded the reduction of corruption and supporting the rule of law.

Viktor Yamukovych, the new prime minister brought changes in Ukraine in 2006, which pleased both EU and Russia. The relation between EU and Russia depended on a large number of mechanism such as joint structure, (permanent council, working groups), bilateral agreements, strategies and partnership agreement (Gormant, 2008). Russia being the largest geographical entities on the European continent, Russia and EU are interdependent in many ways, joined by common civilization roots, culture, history and bright future. The heterogeneous nature of EU created 27 different voices. Mark Leobard and Nicu popescu identified five (5) groups of distinct policy approaches (Leonard, 2007) 
1) Trojan Horses (Cyprus and Greece) always defined Russia interest in EU system and veto common EU positions.

2) Strategic partners (France, Germany, Italy and Spain) which enjoy special relationship with Russia and undermines EU policies

3) Friendly pragnatists (Austria, Belgium, Bulgaria, Finland, Hungary, Luxembourg, Malta, Portugal, Slovakia and Slovenia) maintain a closed relationship with Russia and put their business interest above political goals

4) Frosty pragnatists (Czech Republic, Denmark, Estonia, Ireland, Latvia, the Netherlands, Romania, Sweden and the United Kingdom) focus on business interest but find it difficult to speak against Russia human right abuses.

5) New cold warriors (Lithuania and Poland) have hostile relationship with Moscow and use veto to block EU negotiations with Russia.

Political Russia was no more attractive to its neighbour until democracy was embrace (Emerson, 2005). Russia attitudes towards the west was improved after the 2000 elections and the economy was picking up with Vladimir Putin strengthen Russia's international position.

The effect of regional leadership on Ukraine. Ukraine crisis escalated which led to its clashes between authorities and protesters. It claimed many lives since the country differentiated itself from soviet influence. Russia viewed towards leadership style of certain parts of ex-soviet states created conflict whereas the expanding nature of European normative and cultural influence had increased in the last 15 years with the biggest new waves of member states. This was where the conflict stands. European had 13 new members in the last decade. Ukraine is an ethno-cultural, Greco-Roman and Christian civilization alongside Europe and EU despite its soviet past, its self-aggrandizing, political class and decidedly uncivic state (Sherr, 2013). EU is also regarded by Ukraine as a source of wealth and development, a view embraced by Ukraine politicians. The technocratic biases of EU elites and the integration process may assist in this regards. Also Ukraine real division within the EU-28 signifies the potential and importance (Sherr, 2013). Following the agreement between EU and Ukraine. The association agreement became a stand point with the focus on EU and Russia interest in Ukraine. The EU ordered Ukraine to full 3 conditions (1) by complying with international standard of electoral practices (2) Keeping a stop to selective justices (3) implementing the reforms agreed jointly in the Association agenda (Sherr, 2013). At the same time, Russia was putting pressure on Ukraine to back out from EU terms. This was perceived as a huge blow on EU leaders who pointed figures at Russia on Ukraine.

There were different leadership styles between EU and Russia in this situation on Ukraine. Whereas the formal was constructive in a series of agreement and multinational plan, the later actions were move spontaneous with a greater short term impact. Without having a clear idea as to which direction to go there were a number of aspects which were clear at ago. (1) The direction that Ukraine make in the future will impact on countries political both short and long term. The second solution to Ukraine was no means complete solution. Russia was deemed fit to make flexible its military muscle within its boundaries of new Europe. The success of this action encouraged new strategic thinking for both West and Russia, but 
affected both economically and security stability in the region with countries such as Poland calling for sanctions and US missile defense system.

\subsubsection{Leadership in Ghana and Its Impact}

An attempt has been made to review literature for tracing historically different types of leadership in the political governance in Ghana and their influent on economic development in Ghana: Ghana has had an impressive recognition of a peaceful country where freedom and justice are permitted in the constitution. Ghanaian leadership style is autocratic, with decisions descending from top to down. Adekola et al. (2016) argues that Ghanaian leaders view their authority, profession and information as their personal property.

A book worth reading is Ken Ofori-Atta's leadership, Entrepreneurship and values. The minister of Finance has authored the book in 2009 in order to motivate and attract readers' personal life and career for the betterment of the young generation. The book gave an excellent overview of the current situation of leadership in which Ghana is going through hard times-like this and the type of leadership it has to adopt. Another book of charm for those with a keen eye on local leadership analysis in Ghana's leadership and Nation Building by professor Stephen Adei. The professor highlighted an insight on Ghanaian leadership. He described great leaders of Ghana in detail, giving a true picture of how others perceive these leaders.

Professor Stephen Adei stated that in order to build a nation like Ghana, effective leadership are needed. He opined that reckless leadership was ruining Ghana and also it lacks requisite leadership. He presented strength and lamented from an augmented perspective that leadership factor was the most vital in the determinant of national progress. He distinguished the concept of leadership from the popular opinion of that leaders are by his assertion illustrating cases of five different countries that have helped in the nation building.

Joseph Stiglistz in his book,' Making Globalization work' stated that development is concerned about transformation of people, but not transforming economies. Ban Ki-Moon stated that 'we need to go beyond gross domestic product as our main measure of progress, and fashion a sustainable development index that puts people first' (Former UN Secretary -General Ban Ki-Moon-Remarks to the High-level Delegation of Mayors and Regional Authorities, New York, USA, $23^{\text {rd }}$ April, 2012).

Ghana is within the sub- Sahara Africa and the region is regarded as one of the most corrupt places on the continent of the world. This is one of the major factors that contributed to the slow socio-economic growth of the region. Overwhelming, $\$ 150$ billion is lost to corruption each year by blowing away investment and high-value projects, compared to \$25 billion of foreign Aids channel to the region per year. This proves that the region developmental goals is also relied on foreign Aids.

Ghana's economic development is made up of two distinct economic strategies which has been pursued by the government of Ghana. There was economic planning before Ghana's independence 1957, where government managed resources allocation through to the late 1970 and early 1980s. The implementation of Structural Adjustment Programme which was monitored by World Bank and IMF in 1983. 


\subsubsection{Post -Independence Politics}

At independence, Ghana had physical and social infrastructure and \$481million reserves. After independence, the convention people's party (CPP) under Dr Nkrumah took the path of industrialization. It established so many state farms and enterprises across the nation to fulfill its dream. By 1960, Ghana has been positioned for a brighter future. Ghana standard of living in terms of Gross domestic product (GDP) was 7.6\% and per capital income was 70 British pound excellent than other sister countries like Nigeria (29 British pounds), Egypt (56 British pounds), and India (25British pounds), (Huq, 1989). But the failure to address low productivity in the agriculture sector and solely relied on major cash crop (cocoa) shattered the industrialization pursued. Instability in the 1960s created fear and panic for investors to channel their hard earn money into a dice environment like Ghana. The major mistakes Ghana made initially was the adoption of the socialist model of economic policies as compared to the market based economic system inherited from the colonial masters (British) after independence. It also did not strategically adapted a friendly and hospitable environment to attract foreign direct investment into the country. It also prevented inclusive government, did not allow institutions to mobilize resources, embracing inclusive economic growth and reduce poverty to the minimum level.

Various Development Plans from 1920-1980

\begin{tabular}{lll}
\hline Specific development plan & Period & Remarks \\
\hline Ten-year dev't plan & $1920-1930$ & $\begin{array}{l}\text { Help to promote social \& } \\
\text { physical Infrastructure }\end{array}$ \\
\hline Ten-Year devt plan & $1946-1956$ & Had very little impact \\
\hline Ten-Year devt plan & $1951-1961$ & $\begin{array}{l}\text { Decision taken to implement } \\
\text { the plan }\end{array}$ \\
\hline Consolidated plan & $1951-1959$ & \\
\hline Interim plan & $1958-1959$ & Drop out in 1961 \\
\hline Five year plan & $1959-1964$ & $\begin{array}{l}\text { Suspended in 1966 coup } \\
\text { Suspended in 1966 coup }\end{array}$ \\
\hline Reconstruction and Devt & $1963-1964$ & \begin{tabular}{l} 
Belief in private sector \\
\hline Two year devt plan
\end{tabular} \\
\hline One year devt plan & Mid 1969-1970 & $\begin{array}{l}\text { Commitment to private } \\
\text { sector growth }\end{array}$ \\
\hline Five year devt plan & Mid 1970 to mid 1971 & $\begin{array}{l}\text { Remained on paper work } \\
\text { only seriously suffered from } \\
\text { implementation }\end{array}$ \\
\hline
\end{tabular}

Source: Huq (1989). 
Economic Planning: The ten year development plan was launched by the visionary leader the late Dr Kwame Nkrumah, to drive the nation forward economically and position it among the advance countries. He invested 876.3 million British Pound and his main aim was to build a socialist state, so as to achieve a faster economic growth (GoG, 1964).

Infrastructure: Under the leadership of the late Nkrumah, he invested 74 million British pounds for infrastructure development. This was one of his greatest economic priority as pinpointed by Omaboe (1966).

Financial inclusion including savings: The government motivated its citizens to work hard and live a happy lifestyle. It built a lot of financial institutions and encourage citizens to save for the future. This made Ghana's savings rate to be high and encourage greater capital per person.

Education: Citizens were motivated to attend school and this closed the knowledge gap in education. Majority of the students were sent to former Soviet Union for further studies. They were to return to Ghana and contribute their quota to help in the development of the country.

Agriculture modernization: Ghana depended on export primary commodities such as cocoa, timber and rubber. A lot of States farms were implemented throughout the country by the first president.

The late Dr Kwame Nkrumah was a visionary leader full of wisdom with the nation at heart. He had solid policies combined with good governance to transform Ghana to a modernized society.

Ghana needs a servant leader like the late Dr Kwame Nkrumah who will set good economic policies, governance and accountable to the citizens.

On February 24, 1966, the Ghanaian Army and the Police in addition with external architects over threw the Nkrumah's regime. There was no concrete solution to Ghana's problem, especially since its economic development was of little relevance to the continent after the coup. But after the over-thrown of Dr Nkrumah, Ghana had no brilliant generals and cabinet ministers to lead the country, and there was a leadership vacuum been created.

\subsubsection{Post- Nkrumah Policies}

The military handed over to the civilian authority under the second republic in October, 1969 after a parliamentary election in which Dr Kofi A. Busia won majority of the set. In a special election on $31^{\text {st }}$ August, 1970 former Chief Justice Edward Akufo-Addo became the president with Dr Busia as the prime minister.

The period saw the implementation of a two year Development plan which took place between mid-1968 and mid 1970 period and a one year plan covering the period of mid-1970 to mid-1971. The inability to control the sinking ship paved way for the bloodless coup on January 13, 1972. When a new military coup under the National Redemption Council (NRC) took place in January 1972, both the two year and one year plan were not initiated with long term perspective. They were prepared in favour of different policies and agenda as the case of the seven year plan. The two year plan was in line with private enterprise and the expansion of investment in the sector. The government declared the economy as private enterprise and decided to rely on it (GoG, 1968b). The one year plan was in consolidating the two year plan as a strategy. The government focused mainly on the private enterprise because of it high 
efficiency in the sector. The planners emphasized the backing of the private enterprise with less sponsoring of the state owned enterprises (GoG, 1970).

General Acheampong's regime miraculously managed the economy without any development plan put in place. They used a try and error strategies to survive. None of these strategies could survive. A five year plan 1975 -1980 was first published in January, 1975 but surprisingly it was formally launched in 1977. The planned investment was 2,192.3 million cedis arrived from different sectors of the economy with investment capital output ratio of 3.1 (GoG, 1977a). The five year plan was similar to the previous seven years plan. It envisaged greater participation in direct production and it was to build a solid economy through a policy of self-reliance (GoG, 1977a). The architect believed that manufacturing industry was more important in the economy linking it with import-substitution industrialization strategy (GoG, 1977a). Details of the plan was mainly concerned with growth rate in the secondary sector due to large scale industries, making the industrial policies and programmes been formulated to absolve increased in investment in manufacturing activities (GoG, 1977a). The GDP was estimated to be $5.5 \%$ per annum during the plan period.

The five year plan was weaken due to non-implementation of but was used as a framework by the ministries and investing agencies towards achieving the food self-sufficiency objectives of the government. The government was reluctant in its implementation after it was published. Government budgets were in deficit, combined with increase in salaries and wages which went contrary with the five year development plan resources balance.

Friction led to the arrest of General Acheampong in July, 1978 by his chief of staff Lt General Frederick Akuffo. He was not able to tackle Ghana's economic challenges nor arrest corruption in which senior military officers were involved. On June 4, 1979, a group of junior officers led by its chairman Flt Lt Jerry John Rawlings and noncommissioned officers Armed forces Revolutionary council deposed a violet coup against General Akuffo. The AFRC executed eight senior military officers, inaugurated Tribunals secretly without due process, tried the officers with individuals for corruption, sentencing them for too long and confiscating their properties.

The AFRC permitted presidential and parliamentary elections to be scheduled on June and July and handling over power to the new president and parliament of the Third Republic on September 24, 1979. The new president, Dr Hilla Limann, instituted the constitutional constitutions and respect for democracy and human rights.

The Limann's government established a five year plan, which was called Government Economic programme 1981/1982-1985/1986. The document was not published because of the military takeover in December 1981. There was encroachment on people's liberties gradually and was to be perceived by the less watchful. There was price control which had been in operation and affected all production system in all the sectors of the economy. The black market economy in 1981 took two-fifths of the GDP (Huq, 1981). The fall of the national currency was a worrying to the extent that by 1981, one cedi was equivalent to one-tenth of the 1971 purchasing power. There was a fall in the external value of the cedi in which the exchange rate was fixed at 1.15 cedi per US dollar from December 1973 to September 1978 and further devaluation at 2.75 cedi per US dollar to October 1983 (Huq, 1989). 
The supply of foreign exchange falls short of local demand, and therefore created a black market in the hard currencies, the rate that was fast accelerating bringing in balance in supply and demand. The black market of the US dollar rose threefold in September, 1978 and fifteen fold in October, 1981 and further twenty-six fold in march 1983. In early 1983, the economy was in shambles and at the vent of total collapse leading to a fall in government development expenditure deterioration in critical infrastructure services such as roads, railways, electricity and telecommunications. The sunk in infrastructure services such as transport affected the export products to ports for shipment, which further deteriorated export earnings and taxes. The distortion led to the overt valued the exchange rate and brought shortage of imported food stuffs, induced farmers to move out of the export to produce for the domestic market (World Bank, 1984). This collapsed export in a great way.

\subsubsection{Economic Recovery Programme from 1983-1989}

The provisional National Defense Council (PNDC) government drafted a two volume economic recovery programme, which was released in August 1988 (GoG, 1983a). The main purpose was to revised the prolong sunk economy, characterized by financial mismanagement, inflation rates upwards over $100 \%$ and extensive government interference in the economy (IMF, 1998). The government in power by then organized a rescued Economic Management team led by Dr Kwesi Botchwey and Joe Abbey to help resurrect the dying economy. Both the IMF and the World Bank were to assist the great team, correct all imbalances and deviations shape the economy and bring it back on track (Ackah et al., 2012b). The economic recovery program exhibited by the Ghanaian strategic economists brought hope to the country and the continent as of today. It purposes was to breach the infrastructure bottleneck and turn around the productive sectors (agriculture, mining and timber) for the better and arrest inflation through fiscal and monetary discipline.

\subsubsection{The Fourth Republic}

International and domestic pressure forced the military to return to democratic rule. This was because as we already know, too that revolution does not refer to change. The French had dozens of revolutions since 1789, yet the more revolutions they had, the more they find themselves living under the same regime. On May 18, 1992, the total bans on political parties were lifted for the preparation of the multi-party elections. On January7, 1993, the fourth Republic was found in which Flt Lt Jerry John Rawlings was inaugurated as president and members of parliament were sworn into office.

In December, 2000, another election was held and the first democratic President John Agyekum Kuffuor emerged. The government of J. A. Kuffuor enjoyed the support of Ghanaians, and they pursued domestic political agenda based on the public commitment to the rule of law. Human right and free market initiatives were established.

In early 2000, the country enjoyed a considerable extent of debt relief under the Heavily Indebted poor country (HIPC) programme and the multi-lateral Debt Relief initiative which involved considerable capital inflows. The economic reforms made by John Kuffuor and improved working of the economy attracted foreign investment especially privatized gold mining industry. The amount of foreign exchange helped in strengthening of the economy. Privatization of state-owned companies and public service provides help in the institution 
reforms and led in the creating of new regulating bodies.

During former president John Kuffuor economic reforms, the GDP in 2003 was \$ 7.5 billion and real GDP growth rate was $5.2 \%$ combined with per capita GDP (2003) was $\$ 365$. Inflation rate was down in 2003 at $23.6 \%$

John Evans Atta Mills won the presidential election in 2008 and passed away on $24^{\text {th }}$ July, 2012. He inherited $10 \%$ unemployment rate from his predecessor which was one of Ghana's biggest challenges in the country.

Skill development: Under the leadership of John Evans Atta Mills, he noted how the educational system and University training have failed the production process, skills development and technical expertise to be absolved by different industries. The training programs and course content did not arrest the structural imbalances in arrears through previous years. In this scenario, previous polytechnic Institutions in Ghana changed its name into Technical Universities did not add any value to high skill training nor technical expertise to advance courses.

Work Ethics: He noted poor development and growth contributed to low skill development, poor work ethics, lack of infrastructure, none existence of e commerce, inadequate finance combined with poor venture capital to move the economy into advance level.

John Dramani Mahama who was the vice president of the late president John Evans Atta Mills in July, 2012, became the president and served until 2017. He faced worsening economic situation in the country. Falling Ghana export prices combined with accelerating public wages had a great impact on the Ghana's export economy, as well as increasing debt. Power shortage affected his administration when he was named Mr. 'Dumsor' (Meaning irregular light is on and off) describing power shortage which was having effect on the economy.

Infrastructure: Poor infrastructure in many sector of the economy has caused a huge drawback towards growth and advancement. John Dramani Mahama inherited these challenges under the leadership of Evans Atta Mills and managed to develop them. He did his best but was distracted with various scandals under his presidency. Economic woes and power shortages combined with escalating scandals largely cost him losing the 2016 presidential and parliamentary elections to Nana Addo Akufo Addo.

Nana Akufo Addo Economic Outlook

Economic outlook by World Bank; Ghana's annual economic growth was strong at $8.1 \%$ in 2017 then swindled to $6.3 \%$ in 2018. Its muscle was in mining, petroleum, agriculture and in forestry and logging. The economy accelerated to $7.6 \%$ in 2019 by the help of oil and non-oil sectors. Policy interventions turn round the non-oil sector with a boost in agriculture sector. Whereas industry was to streamline the productive sectors. Fiscal consolidation is weak in 2019 with domestic revenue mobilization trying to turn around in the medium term.

The 2017 Budget gave hope that could turn round the economy to long term with a major macroeconomic variable: (1) Overall GDP growth rate of 6.3\% (2) End year inflation rate $11.2 \%$ (3) Overall fiscal deficit of $6.5 \%$ of GDP (4) Gross Foreign Assets to cover at least three months of imports. The budget introduced major policy initiatives which paved way to tax incentives to promote trade, beef production which will accelerate employment and 
withdraw the rural-urban shift unemployment persons. In his 2019 budget presented to the parliament, the finance minister, Hon Ken Ofori Atta promised a stronger economy for jobs and prosperity.

The government medium term macroeconomic targets for (2019-2022) were as follows. Average over all Real GDP growth was to be 7\% with Average non-oil Real GDP growth to be $6.5 \%$. Inflation target band to be $8+\ldots$ with over all fiscal deficit rule to be $3-5 \%$ of GDP. Primary balance surplus was to $>1 \%$ of GDP. Gross reserves international cover $>4$ months of imports. Priority areas was to transform Ghana beyond Aids

On Agriculture modernization, the need for job creation and livelihood. Industrialization and infrastructure to be on course. Affordable housing and mortgaging combined with investment in human capital. Efficient public delivery in addition with domestic resources mobilization. Moreover, strengthening the financial service sector was a concern. But Dr Bawumia and his economic management team have promised Ghanaians to rebuild the economy by transforming it through digitization.

Yuval Noah Harari, in his book' 21 lessons for the $21^{\text {st }}$ century' pinpointed that with the high speed and changes in advanced technologies. People without the requisite skills will not be able to cope within the $21^{\text {st }}$ century. This has been a blow to Ghana due to its slow pace in technological skill development. Ghana has not able to change gear to embrace rapid changes in technological and make huge advancement in data utilization, computation, data analysis, data mining, automation, and artificial intelligence and embraced economic integration among the sub region of West Africa.

The government is also struggling with the unemployment rate in the country; though it has tried it best to give temporary jobs to cushion the pressure on unemployed graduates. It has given Ghanaians free water service and $50 \%$ electricity bill for Ghanaians to suppressed the hardship due to corona virus disruption of household incomes.

The Minister of Employment and Labour Relations stated in parliament during his vetting on February, 2021 that the government has created 3 million jobs from 2017-2020 even though no data was provided to back the claim at the vetting. But in an article entitled 'Microfinance in Ghana, Due diligence on micro financial system management towards reduction in poverty and unemployment' which was published by Macrothink Institute, February 2019 by David Kwasi Mensah and Dr. V. Rengarajan,'the problem related to unemployment according to Ghana Statistical Services (GSS), over 1.2 million able bodied youth from ages 15 years and above which represented $11.9 \%$ of the labour force were jobless.

Education

Primary, Junior and Senior secondary education are tuition-free and mandatory by the government. The free senior secondary school was implemented by president Nana Akufo Addo, immediately he took office in 2017. The government support for free senior secondary education has been welcome by almost every Ghanaian in the country. His vision was to make sure that low income parents especially the vulnerable are able to send their children to secondary school.

There are about 100 or more institutions in the country which are both public and private universities. These institutions offered the British National Diploma (HND) and degree 
courses. In 2003 and 2004, the total enrollment into public Universities were 18,149 and that of private Universities were 1,380 and a total of 8,688 went into Technical Universities representing $30 \%$ increase from the previous years. Total population into tertiary education has passed over 100, 000 students in the history of Ghana.

\subsubsection{Why Ghana Lags Behind Other Developing Countries in Financial Inclusion}

Ghana is included in African countries with the least banked on the continent, and an estimated of $80 \%$ of its billion people facing challenges of formal banking services, and of which on the average $69 \%$ of adults have an account. The World Bank pinpointed that only $24.8 \%$ of adult population in Sub-Sahara Africa including Ghana have open an account. It is only $14.8 \%$ of adult uses a debit card, percentage compared to other developing countries such as Asia whose percentage of owing a bank account and a debit card are 53.2\% and 32\%. For Middle East and North African countries the percentage is $47.7 \%$ and $36 \%$, for Latin America countries the percentage is $46.7 \%$ and $31.2 \%$ and Europe, it is $58.1 \%$ and $43.2 \%$.

Financial inclusions break down by Accounts in Ghana as at $14^{\text {th }}$ June, 2019

\begin{tabular}{ll}
\hline Mobile money & $20 \%$ \\
Banks & $34 \%$ \\
Non-bank & $8 \%$ \\
\hline
\end{tabular}

Financial inclusion in Ghana

Total financially included

Non total financial inclusion

Total
$48 \%$

$52 \%$

100

$17 \%$ of Ghanaian adults are actively using a registered mobile money account.

Mobile money Awareness and use

\begin{tabular}{ll}
\hline Awareness & $99 \%$ \\
Non awareness & $1 \%$ \\
Total & 100 \\
\hline
\end{tabular}

Source: www.finclusion.org/country/africa/ghana.html\#dataAtAGlance

Ghanaians have almost the same level of access to banking and mobile money (36\% and 29\% respectively). Six (6) differences in financial and economic growth between French and English speaking economies of West Africa.

British Colonial Banks

The banking system established by British in the colonies were the English model known as 
the Anglo-Saxon model, which were market-oriented and the banking institutions acted as deposit-taking institutions. The role of these institutions was to mobilize savings, and took on a strong intermediation role at a large stage. Economic historians wrote substantially on colonial banking in British West Africa (BWA) which comprises of Gambia, Sierra Leone, Ghana, Nigeria and the Anglophone part of Cameroon.

French Colonial Banks

French organized its colonial rule under the French West Africa Federation. French banks set up branches in the colonies. In each colony, French issued currencies joined to the French Franc. The currencies of the other colonies were consolidated into one currency---La Franc des colonies francaise d' Afrique. The idea was to have a broad Fran zone in the colonies with convertibility into the French franc and fixed parity. In 1945, the common currency in the colonies were the CFA (French community of Africa). In 1962, there were regional banks which were consolidated into just two: The Banque centale des Etats de l'Afrique de l'Ouetst (BCEAO) for the West Africa zone and the Banque des Etats de l'Afrique Centrale (BEAC) for the Central Africa Zone. The BCEAO headquarters was in Dakar while the BEAC headquarters was in Yaounde (Kirk \&Bach, 1995). Despite the two official currencies being different and only one legal tender in their respective zones, they were all referred to as the CFA franc. Both CFA franc were pegged to the Euro and convertibility was guaranteed by France. Countries in each currency zone pool their foreign currency reserves. Half of the reserves were deposited with the French Treasury.

Despite the arrangement of being a colonial legacy, it has brought financial stability in Francophone Africa as well as eliminating the risk of foreign exchange rate fluctuations in trading with Europe, the region's largest trading partner. The Economist (2018) provides evidence regarding stability by citing that over the past 5 decade, inflation in cote d' lvoire averaged 6\% whereas that of neighboring Ghana, a non-Francophone state, average $29 \%$.

\section{Methodology}

An explanatory is based on insight collected from existing literature of different studies, periodicals and books concerned to the topic of study in order to investigate the correlation between leadership and economic development of Ghana. A descriptive analysis is made using secondary data culled out from various literature and official records. The research will help us to acquire vital information on the subject area. Drawing on existing literature with the main topic in consideration, it will formulate and discusses the prepositions which will back leaders for good political and economic transformation of a developing country like Ghana. Limitation. There might have been some flaws in the implementation of the data collected.

Table 1. Macro-economic Developments

Selected Macroeconomic indicators, 1961-2015

\begin{tabular}{lllllllll}
\hline Period & EP & MP & TB & GDP & AF & GR & GE & FB \\
\hline $1961-1965$ & 21.63 & 28.57 & -.6 .94 & - & - & 20.10 & 29.59 & -9.49 \\
\hline $1966-1970$ & 18.73 & 20.68 & -1.95 & - & 4.61 & 15.93 & 20.58 & -4.65 \\
\hline
\end{tabular}




\begin{tabular}{lllllllll}
\hline $1971-1975$ & 19.03 & 18.44 & 0.59 & - & 17.05 & 14.91 & 18.43 & -3.52 \\
\hline $1976-1980$ & 10.86 & 11.52 & -0.66 & 0.10 & 70.30 & 8.83 & 15.86 & -7.03 \\
\hline $1981-1985$ & 6.47 & 7.73 & -1.26 & 0.20 & 62.33 & 4.54 & 7.88 & -3.34 \\
\hline $1986-1990$ & 17.61 & 24.11 & -6.51 & 0.16 & 31.65 & 14.55 & 9.49 & 5.06 \\
\hline $1991-1995$ & 20.84 & 32.08 & -11.24 & 1.74 & 27.48 & 18.93 & 12.81 & 6.12 \\
\hline $1996-2000$ & 35.85 & 51.34 & -15.48 & 2.33 & 25.33 & 19.58 & 14.08 & 5.50 \\
\hline $2001-2005$ & 40.86 & 59.68 & -18.82 & 1.47 & 20.43 & 25.95 & 29.90 & -3.95 \\
\hline $2006-2010$ & 26.70 & 42.85 & -16.15 & 7.04 & 13.63 & 15.70 & 20.24 & -4.54 \\
$2011-2015$ & 39.01 & 50.67 & -11.65 & 8.01 & 12.43 & 21.77 & 26.72 & -4.95 \\
\hline
\end{tabular}

SOURCES: World Bank (2016a).

EP---Export

MP---Import

TB---Trade balance

GDP---FDI \% of GDP

AF--- Annual inflation

GR----Government revenue

GE----Government expenditure

FB----Fiscal balance

From Table 1, the Ghanaian economy started to bounce back due to strict economic recovering programme (ERP) which was launched in 1983. This appears to be the magical tool in the history of Ghana and the sub region of Africa. The overall objectives of ERP were to promote macroeconomic stability. With regards to revenue mobilization, from 1998-2000, there was a dramatically wonders in improved domestic revenue mobilization. Tax administration was strengthened. There was a total restructure of the tax system, which brought the introduction of the value Added Tax (VAT) replacing the sales Tax and broaden coverage to thee service and retail sectors. Tax identification numbers were also introduced to target groups of the tax payers.

Monetary policy and financial sector reform had a great impact on the economy between 1998-2000.Reduced inflation was magical with the help of controlled monetary growth and reserved money. The government was able to encourage savings mobilization of individuals which turn around the net inflow of capital. 
Table 2. Central Government capital and Recurrent Expenditure, 1961-2015

As percentage of GDP

\begin{tabular}{llll}
\hline Period & Capital expenditure & $\begin{array}{l}\text { Recurrent } \\
\text { expenditure }\end{array}$ & Total \\
\hline $1961-1965$ & 11.08 & 18.46 & 29.54 \\
$1965-1970$ & 4.61 & 15.97 & 20.58 \\
$1970-1975$ & 3.99 & 14.44 & 18.43 \\
$1975-1980$ & 3.98 & 11.89 & 15.86 \\
$1980-1985$ & 1.03 & 6.85 & 7.88 \\
$1985-1990$ & 2.49 & 7.00 & 9.49 \\
$1990-1995$ & 3.95 & 8.86 & 12.81 \\
$1995-2000$ & 5.09 & 8.98 & 14.08 \\
$2000-2005$ & 10.19 & 19.71 & 29.90 \\
$2005-2010$ & 6.42 & 13.83 & 20.24 \\
$2010-2015$ & 5.48 & 21.24 & 26.72 \\
\hline
\end{tabular}

Source: Computed from table B.10 in Appendix B, the statistical Annex.

Table 3. Liberalization of Trade, 1983-2015

\begin{tabular}{ll}
\hline Period & Liberalization moves \\
\hline $1983-1986$ & Bold attempt to liberalization \\
$1986-1989$ & Time of import liberalization \\
$1989-1994$ & Actual Liberalization of trade regime \\
$1994-2015$ & $\begin{array}{l}\text { Exemption to attract foreign investment, } \\
\text { especially in the mining sector and in the } \\
\text { same manner of regional integration which } \\
\text { absolved the bulk }\end{array}$ \\
\hline
\end{tabular}

Sources: Laryea and Akuoni (2012, pp. 189-190), Aryeetey et al. (2000), and Aryeetey and Kanbur (2017), Bajracharya and Flatters (1999).

The state was transforming aggressively through its economic reforms and trade policies which aim at turning the economy from bigger state controlled one to a robust economy in the 1990s. During the 1990s, there were serious reforms and reversing inwards looking bogus policies that were pursued. It includes structure adjustments reforms both in real and financial sectors of the economy. Trade and investment liberalization. Liberalization were subset of them. The opening of the economy changed gears in both imports and exports accelerating as a proportion of GDP but consistently exceeding the initials and changed fifth gears over time. 


\section{Al Macrothink}

Savings

Gross domestic savings is a subset of GDP. Economic thinkers such as Arthur Lewis (1954, 1955) and Walt Rostow (1960a) pointed out the importance of savings and investment which encourage economic growth and development. Ragnar Nurka (1853) and Hla Myint (1964) stated that low income countries with vicious cycle of poverty resulted in low savings, low investment and back to low savings, low investment and back to low income. Lack of responsibility to break the monster poverty by raising the savings standard and investment to national income levels to lower standard of living and a burden on the society. Low savings and investment by the Ghanaian populace in the mid-1980s was one of the major factors contributed to the decline in national income.

Table 4 illustrate per capita income and savings data for a group of selected countries, including Ghana from 1990-2015

GNI per capita and gross savings rates in selected developing countries ( $\%$ of GDP), 1990-2015. Selected years

\begin{tabular}{lllllll}
\hline Countries & GHI per capita (US\$) & \multicolumn{2}{l}{ Selected years } & & \\
\hline & & 1990 & 2000 & 2010 & 2014 & 2015 \\
\hline Asia & & & & & & \\
\hline Bangladesh & 1,036 & 16.43 & 26.95 & 38.46 & 37.73 & 36.10 \\
\hline China & $4,495(2010$ & 38.47 & 36.23 & 51.27 & 48.67 & NA \\
\hline India & $1,679(2014)$ & 23.11 & 25.00 & 34.16 & 33.17 & NA \\
\hline Vietnam & 1,586 & 20.42 & 27.95 & 30.47 & 30.38 & 26.91 \\
\hline South Korea & 25,132 & 33.90 & 34.25 & 34.82 & 34.47 & 35.54 \\
\hline Africa & & & & & & \\
\hline Ghana & 1,645 & 10.53 & 15.27 & 15.13 & 18.49 & 17.57 \\
\hline Nigeria & $2,468(2014)$ & 22.97 & 29.36 & 25.47 & 22.24 & NA \\
\hline Tanzania & 828 & 10.09 & 12.61 & 19.21 & 20.50 & 22.69 \\
\hline Uganda & 655 & 5.59 & 14.36 & 18.94 & 19.48 & 16.01 \\
\hline Cote d'Ivoire & $1,272(2013)$ & NA & 13.29 & 15.31 & 15.84 & NA \\
\hline
\end{tabular}

Source: World Bank (2016a)

NA: Not applicable.

\section{Conclusion}

Poor quality of national leadership may have led to slow rate of Ghana underdevelopment. The leader should be able to determine the vision, goals and value of the nation, provide strategy for achievement, manage change and national transition. He /She should be of ethical behaviour and have outstanding credibility. The leader should have collective responsibility 
and the welfare of the citizens. The above literature and analysis affirmed that good leadership, governance, sound economic policies and strong democracy has led to the success of the advance nations leaving the poor nation like Ghana behind. It is therefore suggested that Ghana should change its leadership style and adopt lazier faire type which has led America, Britain and Singapore to become engine of growth of world economies. Lazier faire will ensure sustainable economic development and poverty cure of the country.

\section{References}

Achebe, C. (1983). The trouble with Nigeria. Enugu, Nigeria: Fourth Dimension.

Ackah, C., Aryeetey, E. \& Opoku, K. (2012). Wages and employment effects of trade liberalzation: The case of Ghana manaufacturing. In C. Ackah, \& E. Aryeetey (Eds.), Globalization, trade and poverty in Ghana. Accra-Legon: Sub-Sahara Publishers.

Adekola, A., \&Sergi, B. S. (2016). Global business management. A cross-culture perspective. Rutledge. https://doi.org/10.4324/9781315584744

Alishebami, A., Al-jubari, I., Alyoussef, I., \& Razza, M. (2020). Entrepreneurial education as a predicator of community college of Abqaiq students 'entrepreneurial intention. Management Science letters, 10, 3605-3612. https://doi.org/10.5267/j.msl.2020.6.033

Ang, P. (2015). Time for Singapore firms 'to venture out'. Business Times, March 6.

Aryeetey, E., \& Kanbur, R. (Ed.) (2017). The economy of Ghana: Sixty years after independence. Oxford, Oxford University Press. https://doi.org/10.1093/acprof:oso/ 9780198753438.001.0001

Aschauer, D. A. (1989). Does public capital crowdout private capital? Journal of Monetary Economics, 24, 171-188. https://doi.org/10.1016/0304-3932(89)90002-0

Bajracharya, R., \& Flatters, F. (1999). Ghana's trade policies: Tariff rate structure and revenues. Retrieved from https//qed.ecom.queensu.ca/faculty/flatters/writings/

Bissue, L. L. (1967). Ghana's seven year development plan in Retrospect. Economic Bulletin of Ghana, 11(1), 11-44.

Burns, J. M. (1978). Leadership. New York, NY. Harper Collins.

Chenery, H., \& Strout, A. M. (1966). Foreign assistance and economic development. America Economic Review, 56, 679-733.

Cohen, M. (2015). Lee Kuan Yew 'Doesn't Trust' the nation he built. Retrieved from www.forbes.com

Collins, S. M., \& Bosworth, B. P. (1996). Economic growth in East Asia: Accumulation versus assimilation. Brookings Papers on Economic Activity, 2, 135-203. https://doi.org/10.2307/2534621

Constantin, V. T., \& Bogdan, P. Leadership scenarios in Ukraine. The impact of EU and Russia politics.

Covery, S. K. (2002). Servant leadership and community leadership in the twenty-first century. In L. C. Speang, \& M. Lawerence (Ed.), Focus on leadership. Servant leadership for the $21^{\text {st }}$ century (pp. 27-34). Wiley, New York.

Demirgae-Kunt, A., \& Klapper, L. (2013). Measuring financial inclusion: Explaining variation across and within countries. Brookings Papers on Economic Activity, 1(1), 41. 
https://doi.org/10.1353/eca.2013.0002

Dike, V. (2003). Nigeria and the politics of unreason: A study of the Obasanjo Regime. London. Adoris \& Abbey Extending financial inclusion in Africa. Edited by Daniel Makina.

GoG (1964). The seven year plan for National Reconstruction and Development 1963-1864 to 1869-70. Accra: Office of the planning commission.

GoG (1968b). Two year development plan: Mid 1968 to 1970. Accra State publishing corporation.

GoG (1970). One year Development plan: Mid 1969-mid 1970. Accra: State publishing corporation.

GoG (1977a). Five year Development plan,1975-76 to 1979-80: Part 1and 11. Accra: Ministry of Economic Planning.

GoG (1983a). Economic Recovery Programme. 1984-1986 (Voll and 11). Accra: Government of the Republic of Ghana.

Habtemichael, F. S. (2009). Anti-corruption strategies in the South Africa public sector. Perspectives on the constitution of complexity thinking and ICTs, Doctoral dissertation, University of Stellenbosch, Sellenbosch.

Ho, K. P. (2015). Europe: Baby Bump Holds lesson for Singapore. Strauts, March 5.

Huff, W. G. (1994). The economic growth of Singapore: Truck and development in the twentieth century. (Cambridge, Cambridge University Press). https://doi.org/10.1017/ CBO9780511470714

Huff, W.G. (1995). What is the Singapore model of economic development? Cambridge Journal of Economics, 19, 735-759.

Huq, M. M. (1989). The economy of Ghana. The first 25 years, since independence. London: Macmillam. https://doi.org/10.1007/978-1-349-19749-1

Ifediba, U. (2003). Military dictatorship. The impact of a tragedy. (1st ed) Ekwulobia, Godament Odey, J. (2007). Another madness called election (2007). (Vol 1) Enugu snap.

IMF (1998). Ghana enhanced structural adjustment facility. Economic and Financial Policy Frame Work Paper, 1998-2000. Retrieved from https//www.imf.org/external/np/ pfp/Ghana/ghana0.htm

Izukanne, M. (2003). Nigeria's quest for democracy 1960-2003: A mirage. Nsukka: Afro-Orbis publishing co.

Jacobson, M. (2010). The Singapore Solution. National Geographic, January.

Jega, A. (2007). Democracy, good governance and development in Nigeria. Ibadan, Nigeria: Spectrum Books Limited.

Killick, T. (1978). Development Economies in action. A study of economic policies in Ghana. London, UK: Heinemam.

Krick, A. \& Bach, D. (1995). State and society in Francophone Africa since independence. London, UK. Macmillam Press.

Langa, P. N. (2006). The separation of Powers in the South Africa constitution. South Africa Journal of Human Right, 22(1), 2-9. https://doi.org/10.1080/19962126.2006.11864878 
Leadership crisis in Nigeria. Theoretical study of John 10: 11-15.

Leipiziger, D. M. \& Thomas, V. (1993). Lessons of East Asia (Washington, D.C, World Bank).

Lewis G. America Today. Foreign Affairs vol. 28.

Microfinance in Ghana. Due Diligence on micro financial system management towards reduction in poverty and unemployment.

Mojapelo, J. P. M. (2013). The doctrine of separation of powers. Advocate, 26(1), 37-46.

Ofoebe, C. (2005). Scramble for Nigeria. Enugu, Nigeria: New Generation Books.

Okoro, B. (1994). Squandermania mentality: Reflection on Nigeria culture. Nsukka: University Trust.

Omaboe, E. N. (1966b). The process of planning. In. W. Birmingham, I. Neustadt, E. N. Peeble, G., \& Wilson, P. (1996). The Singapore Economy (Cheltenham, Edward, Elgar).

Rerry, L. B. (Ed) (1994). Ghana: A country study. Washington, D.C: Federal Research Division Library of Congress.

Rodrik, D. (1997b). TFPG Controversies, institutions and economic performance in East Asia (National Bureau of Economic Research working paper, 59:4), (Cambridge, MA, National Burau of Economic Research). https://doi.org/10.3386/w5914

Rost, J. C. (1991). Leadership for the twenty-first century. New York. NY; Prager.

Ruschman, N. L. (2002). Servant leadership and the best companies to work for in America in LC spears \& M. Lawrence (Eds). Focus on leadership. Leadership for the $21^{\text {st }}$ century. (pp. 123-139). Wiley, New York.

Selvaratnam, V. (1994). Innovation in higher education: Singapore at the competitive edge. (World Bank Technical Paper No 222, Asia Technical Department series) (Washington, D.C, World Bank). https://doi.org/10.1596/0-8213-2618-X

Spence, S. M. Rajah, T., Narayan, S. A., Martin, S., \& Labiri, G. (2007). The Indian CEO: A Portrait of Excellence. Response Books, Los Angeles.

Tanzi, V. (1991). Public finance in developing countries. Adershot: Edward Elgar.

Taylor, L. (1991). Income distribution, inflation and Growth: Lecturers on structuralist macroeconomic theory. (Cambridge, MA, MIT Press).

Thatcher, R. (2012). Leading by example. Brokbrom, London.

The Economist (2018). Franc exchange. In the economist January $27^{\text {th }}$ February, 2nd, 2018.

The Economy of Ghana. London: George Allen and Unwin.

Todaro, M (2016). Economic development. Retrieved from https//www.whatiseconommics.org/economic-development.

Walls, W. J. (2004). 'Anatomy of collaboration'. An act of servant leadership. In L. C. Spears, \& M. Lawrence (Eds). Practising servant leadership. Successs through trust, bravery and forgiveness (pp. 113-132). Josesy- Bass, San Francisco, CA.

World Bank. (1984). Ghana: Policies and programme for adjustment: A World Bank country study. Washington, D.C: World Bank.

World Bank. (2016a). World Development indicators. D.C. Washington. The World Bank. 
WTO: (2001). World Trade Policy: Retrieved May 1, 2017. From https//www.wto.org/english/tratop_e/tpr/_e/tp157_e.htm.

\section{Websites}

https://www.britannica.com/biography/john-Evans-Atta-Mills

www.businessworldghana.com/leadership-and-nation-building/

www.businessworldghana.com/ken-ofori-atas-leadership-entreprenurship

https//www.britannica.com/biography/jphn-mahama\#nf1275805

https//www.graphic.com.gh/features/opinion/leadership-and-economic-development-of-Ghan a

https//www.ghanaweb.com/GhanaHomepage/features/An-analysis-of-some[key-features-tow ards-Ghana-development

https//www.worldbank.org/en/country/Ghana/publication/Ghana-economic-update.

www.finclusion.org/country/africa/ghana.html\#dataAtAGlance

www.medium.com/new-africa-network/west-africas-new-currency-the-end-

https//www.weforum.org/agenda/2012/06/behind-all-good-leadership

https//www.project.com.ng/political-science/political-leadership-and-economic

https//www.eapn.eu/what-is-poverty/causes-of-poverty-and-inequality/

\section{Copyright Disclaimer}

Copyright for this article is retained by the author(s), with first publication rights granted to the journal.

This is an open-access article distributed under the terms and conditions of the Creative Commons Attribution license (http://creativecommons.org/licenses/by/4.0/). 